EUROPEAN UNIVERSITY INSTITUTE, FLORENCE

DEPARTMENT OF POLITICAL AND SOCIAL SCIENCES

EUI Working Paper SPS No. 99/8

\title{
The End of New Industrial Relations?
}

\author{
WILLIAM K. ROCHE \\ Jean Monnet Fellow EUI, and \\ Graduate School of Business, University College, Dublin
}


All rights reserved.

No part of this paper may be reproduced in any form without permission of the author.

(C) 1999 William K. Roche

Printed in Italy in October 1999

European University Institute

Badia Fiesolana

I - 50016 San Domenico (FI)

Italy 


\begin{abstract}
This paper attempts to assess the extent to which a 'new' industrial relations regime has developed in advanced economies over the past two decades and the prospects of new industrial relations. In addition to examining developments in the private sector, the paper assesses changes in public sector industrial relations in the wake of marketization and the vogue of 'postbureaucracy' principles of 'new public management'. The paper considers three major scenarios concerning the 'trajectory' of industrial relations systems in advanced economies. The evidence as to current levels of diffusion, combined with the most plausible scenarios, suggests that a generalized new industrial relations regime is highly unlikely to develop and that new industrial relations arrangements will remain at best but one of a series of competing and coexisting models for regulating relations between employers and unions. We may thus be witnessing the end of new industrial relations both as a generalizable model and as paradigm for comprehending change in unionized employment in advanced economies.
\end{abstract}


A significant body of recent comparative research has been stimulated in major degree by the 'big question' in the discipline during the past two decades: whether 'new' industrial relations arrangements were diffusing ever more widely in response to changes in the organization of production in advanced economies (Locke et al., 1995; Lane, 1995; Kochan et al., 1997). Taking this question as their starting point, a number of studies have returned to the classical comparative theme of understanding commonalities and variations in the experiences of different countries (see especially Locke et al., 1995). Curiously, in consequence, the big question has receded somewhat into the background. This paper seeks to bring it into the foreground of discussion by using comparative and national studies to pose a stark question: are we witnessing the end of new industrial relations? The paper begins by summarizing the argument that postFordist product strategies and production systems and analogous or related public sector trends were leading to the demise of 'adversarial' industrial relations and to radical changes in other established models. It then considers a range of studies and reviews highlighting the limited diffusion of new industrial relations in both the private and public sectors of advanced Western economies. Finally, the paper considers three scenarios regarding the trajectories of industrial relations systems, and the place of new industrial relations arrangements in these scenarios.

Any assessment of new industrial relations has to begin by admitting that the term is loose, imprecise and sometimes contested. The term itself is more familiar in the AngloSaxon literature. In writings on developments in continental European industrial relations systems, other cognate terms are perhaps more commonly found: for example, 'new production concepts' (Kern and Schumann, 1984), 'productivity coalitions' (Windolf, 1989), 'a new productivist covenant between capital and labour' (Rogers and Streeck, 1995;), ‘co-operative IR/HRM practices' (Regalia and Regini, 1995) and 'micro-concertation' (Regini, 1995: ch. 5). We use the concept here to encapsulate the kinds of changes which all such concepts seek to portray: that is, a wide range of industrial relations and human resource practices, which commentary and research suggests have become more common during the 1980s and 1990s. These practices, commonly described as 'new' or 'innovative', cover the areas of pay, work organization, employee and trade union 'voice' or representative arrangements, recruitment and selection practices, performance management systems and provisions for the 
'governance' of firms and workplaces in the most general sense. Many of the practices in question, for example, forms of direct employee involvement, performance-related pay or profit sharing, are not confined to unionized firms and appear to have become more common across the board. Those who write about new industrial relations, however, are particularly interested in the take up and effects of innovative practices in unionized workplaces. Their main concern is how new practices may impact on relationships built over time mainly on the basis of collective bargaining, but also possibly also on the basis of works council structures of various kinds. When occurring in combination, or in 'bundles', new practices are usually regarded - certainly in the Anglo-Saxon literature as the basis of a new model of industrial relations, also variously described as a 'mutual gains', 'jointist', 'partnership', 'joint governance' or 'joint management' model.

The literature on trends in industrial relations during the past two decades falls broadly into a 'first wave' of commentary and research during the 1980s, characterized by claims that a wholesale transformation of prevailing industrial relations and human resource arrangements was underway, and a 'second wave' of research, concentrated in the 1990s, which is much more cautious and sceptical of the degree to which radical change has been in evidence. The literature on changes in the public domain falls less easily into this periodization. Here both projections and empirical studies mostly overlap during the 1990s. Each strand of the recent literature is considered in turn.

\section{The Demise of 'Fordism' and Adversarial Industrial Relations}

The central themes of much of the post-war industrial relations literature concerned how developed economies might foster industrial relations arrangements capable of reconciling their work-forces with the rigours of industrial control systems; how wage inflation and industrial conflict could be contained through incomes policies or other concertative arrangements; how ways might be found to 'humanize' work to counter, in particular, the alienating effects of mass production systems, and how employers and governments might respond to increasingly assertive trade union demands to extend 'industrial citizenship' and promote industrial democracy (Bendix, 1956; Kerr et al., 1960; Crouch and Pizzorno, 1978; Goldthorpe, 1984). 
During the 1980s these themes were eclipsed by a literature urging a new understanding of the challenges facing advanced economies and offering a new prognosis of the progress of industrial relations. In the new literature the pressures of the 1960s and 1970s, especially wage inflation, sluggish economic growth, rising unemployment and industrial militancy, were seen as marking out the closing stages of a mode of production and work organization that had sustained advanced economies for much of the century: the so-called 'Fordist' or mass production model This model was seen to anchor the 'adversarial system' of industrial relations, based in most national, cases on the primacy of 'arms-length' conflictual dealings between management and unions, 'exclusionary' forms of management decision-making, the subjection of employees to close control, and the imposition by unions and employees - albeit to varying degrees and in different ways in different national cases - of controls over both the boundaries between jobs and the pace at which work was performed (Piore and Sabel, 1984; Boyer, 1988; Kochan et al., 1986).

If the economic and industrial relations convulsions of the 1970s were regarded as but the death-throws of Fordism and its associated model of industrial relations, the economic pressures of the 1980s and 1990s were seen as altering both the basis of competition in advanced economies and the character of industrial relations regimes. Mass markets for a wide range of standardized goods and services had become 'saturated', and besides, developing economies now enjoyed significant relative cost advantages in the manufacture of mass-produced commodities. Consumer tastes and preferences in developed economies were becoming increasingly diverse and changeable, and competitive success would progressively hinge on the capacity of firms to produce customized products and services for 'niche' markets. To respond to the 'new competition' firms now had to compete on the basis of innovation and quality, as well as, or even more than, on the basis of cost and price. The advent of flexible computerized machine tools and allied information technologies provided the technological and economic basis on which to respond to such market pressures. Trends in markets as diverse as textiles and fashion goods, machine tools, consumer electronics and cars were held to be emblematic of the 'new competition' (Piore and Sabel, 1984; Kern and Schumann, 1984; Womack et al., 1990; Best, 1990). 
Combining observation, theoretical reasoning and normative injunction, commentators on developments in private markets argued that the emerging 'Post-Fordist' economy could only effectively be supported by a model of industrial relations which broke decisively with the adversarial paradigm, and which deepened and supplemented institutions for co-operative management-union engagement, such as works councils, where these existed. Relations between companies and unions needed to shift from adversarialism to co-operation, as it was now deemed to be critical for the parties jointly to address competitive pressures and harness the knowledge, skills and commitment of the work-force to the imperatives of the 'new' competition. These imperatives included an ongoing acceptance of product and process innovation, a willingness to train and retrain as specific skills and routines became more 'perishable', and joint commitment to the commercial objectives of the organization as the sole basis on which employment security and improved pay and conditions could be obtained. Product and process innovation, the creation and deployment of so-called 'high and broad' skills in the workforce, and employee commitment to commercial objectives, required the creation of new forms of work organization, such as team working, quality circles, total quality management programmes and the like, characterized by higher levels of direct employee involvement. Narrow job speclialization was no longer sustainable; nor were union and employee controls over the 'effort bargain' (Piore and Sabel, 1984; Kern and Schumann, 1984; Kochan et al., 1986).

If what were viewed as the imperatives of production systems were the main drivers of new forms of management-employee and management-union engagement, a range of associated adjustments in employment arrangements were also predicted. To grant unions a 'stake' in new industrial relations arrangements, as well as to allay fears for their institutional security, firms in countries without works councils arrangements might develop joint forums, steering groups and other collaborative structures. In other areas commonly subjected to standardization under the adversarial model, in particular pay and grading, more flexibility was required to recognize levels of skill acquisition, to assign employees to broader grade categories more suited to flatter organizations and to institute 'gain sharing'. Areas like recruitment, promotion and performance monitoring/management, traditionally subject to unilateral managerial control, or possibly to formal or informal joint regulation, would also become subject to cooperation as both parties recognized the priority now attaching to selecting, developing 
and promoting staff with the kinds of technical and behavioural skills required in the new industrial relations order. In industrial relations systems such as that of Germany, where many such areas had been removed from the arena of adversarial industrial relations and made subject to the deliberation of works councils, there would nevertheless be a new imperative for more decentralized ways of promoting co-operative decision-making at the level of work groups (Kern and Schumann, 1984). In the German case, no less than others, the existing balance between collective bargaining and institutions for cooperative decision-making would change in favour of the latter to support the growing prevalence of 'new production concepts'.

In all these ways, the vision of industrial relations in the post-Fordist firm, as articulated by a growing number of commentators, differed markedly from the heavily compromised, tightly regulated and highly proceduralized features of the established 'liberal pluralist' model of industrial relations widely prevalent in Anglo-Saxon countries, and to varying degrees, in Continental European systems. The viison of the new industrial relations differed also from the weakly institutionalized, 'arms-length collective bargaining' of the French system, and from the dual system prevailing in Germany, where co-operation was channelled through works councils often controlled by unions and made subject to national-level union policy on pay and employment conditions. For commentators such institutional differences were of marginal significance compared with common imperatives arising from the 'new production concepts', 'lean production', 'socio-technical systems' and 'World Class Manufacturing' models which exemplified both post-Fordist competitive strategies in their most pronounced or advanced forms (Piore and Sabel, 1984; Kern and Schumann, 1984; Kochan et al., 1986; Womack et al., 1990; Appelbaum and Batt, 1994).

\section{The New Public Management}

Post-Fordist writings focused in the main on the regulatory and redistributive functions of the state and had little to say about modes of service delivery or employment relations in the public sector. Trends in the market sectors of advanced economies appeared to find parallels in developments in the public sector. The mounting 'fiscal crisis' of governments during the 1970s, rooted in rising income maintenance and other social spending commitments and declining fiscal buoyancy, led to curbs on public spending 
and a wide array of reforms in public and social service provision across industrial nations (OECD, 1990; 1995). Commercial public enterprises in European countries were not immune to these pressures, and increasingly faced EU-instigated programmes of deregulation as part of the project of completing the Single Market (Ferner, 1994). Monopoly providers of public utilities, as well as providers of services hitherto subject to extensive regulation, now had to countenance competition from private companies and sometimes from other publicly-owned enterprises, possibly even in other national jurisdictions. At the same time, public enterprises faced increasingly tight EU-controls on capital and current financial supports and subsidies from national governments.

Tighter spending controls were also accompanied by an increasingly influential ideology which sought to apply 'consumerist' principles to public and social service delivery. First advocated by pressure groups, then taken up by governments and increasingly, if not uncritically, adopted by public service unions as a way of defending the 'public sphere', consumerism sought to enshrine new 'consumer-centred' principles in the design and delivery of public services. The consumerist view of public services, which increasingly found expression in 'charters' of various kinds, argued that principles which were pivotal to the purchase of traded goods and services should increasingly provide the paradigm for public services: convenient and jargon-free information on service availability; access to services in places and at times suitable for service 'consumer'; whenever possible, 'choice' as between alternative service providers; a right to redress in the event of the service provider failing to meet standards of delivery - these and related principles seemed to herald in the public sectors analogous pressures to those driving customized or 'niche' product strategies in private markets (Potter, 1988; Epstein, 1990; Harrow and Shaw, 1992; Walsh, 1994).

Prophets of the new public services and the 'new public management' envisaged radical changes in public administration which would alter the face of the public domain (Osborne and Gaebler, 1993). The 'mass' provision of uniform services to passive and supplicant 'clients', in ways deemed satisfactory to bureaucrats and the professions involved in service provision, would no longer represent a defensible model of service delivery - any more than analogous Fordist strategies would prove sustainable in private markets. The few commentators who addressed new organizational forms and the changing public sector labour process from a Post-Fordist perspective viewed such 
changes as a reflection of wider Post-Fordist tendencies in advanced economies ( for a review see Clark and Newman, 1997: 22-5). While the human resource and industrial relations implications of such developments were ambiguous - the emphasis on marketization might clearly clash with the underlying logic of new industrial relations writers who addressed such issues clearly articulated a new industrial relations paradigm as the expected outcome of reforms. This was especially apparent in the highly influential book, Reinventing Government (Osborne and Gaebler, 1993). It was apparent also in a succession of OECD studies of the reform process that widely prevalent canons of 'best practice' in human resource management were being employed as yardsticks against which to judge progress in the public domain (OECD, 1990; 1995; 1996 and see Storey, 1989; Boston et al., 1996).

Cost containment, consumerism and a new and related vogue in applying management principles to public service organizations led to major changes in public administration across virtually all OECD countries from the 1980s. In public service organizations and commercial public companies - those, that is, that had not been privatized under public sector reform programmes - the pace and extent of change were in marked contrast to the stability which had characterized public administration in many countries - war-time conditions excepted. Quasi-market devices were introduced to engender competition: 'purchasers' of services were separated from 'providers'. Executive public service 'agencies' were created and held accountable for the effectiveness with which they managed service delivery. An array of devices was deployed to manage public service organizations on the basis of objectives and targets rather than observance of rules and precedents (OECD, 1995). These developments resulted often in challenges to longestablished models of public service industrial relations and human resource management. More flexible pay fixing arrangements were advocated to allow management greater leeway to respond to regional and occupational pay pressures and to reward staff for differential performance. Advocates of reform urged that working practices and job boundaries be made more flexible and that grading systems should be simplified. Extensive efforts were made to revamp the highly bureaucratic performance appraisal systems common in many countries in order to create more effective tools for 'performance management', based on objective setting, feedback and performancelinked rewards (OECD, 1990; 1993a; 1993b; 1995; 1996). While the constitutional and legal provisions commonly governing union representation for public servants appeared 
less amenable to radical change, joint management-union decision-making and 'partnership' were advocated in countries without works council arrangements in the public service, for example the US and Canada (Osborne and Gaebler, 1993; Kearney and Hayes, 1994; Kernahan, 1993). New paradigms of management, urging similar innovations, were also evident in commercial public companies beset by the commercial pressures unleashed by deregulation and liberalization (Ferner, 1994; Hastings, 1994).

Whether writing about the private or public sectors, the language of much commentary on industrial relations change during the 1980s was of 'transformation' and systemic change. Portrayals of supposed underlying changes in patterns of production and service delivery spoke in terms of 'divides' or 'transitions'. Fordist production systems were giving way to 'post-Fordist'. Economies based on mass production were giving way to economies based on 'flexible specialization' or 'diversified quality production'. 'Old' industrial relations were giving way to 'new'.

\section{Limits to the Diffusion of New Industrial Relations}

This section of the paper considers empirical contributions to the literature on change in industrial relations practices and arrangements during the 1980s and 1990s. It begins with a short overview of the main themes to emerge from more empirically focused treatments of the features of new production systems and 'post-bureaucracy' models of public service delivery. It then moves on to consider the evidence which has emerged on various strands of change in industrial relations practices, and examines developments in public sectors. A series of conclusions are presented based on the pattern revealed by the evidence.

A detailed critique of post-Fordist theories of change in markets, regulatory institutions and production systems is beyond the scope of this study. Criticisms of the central arguments associated with the new paradigm have mounted during the 1990s. Both conceptual objections and empirical evidence have been marshaled against the apocalyptic predictions of the 1980s ( for a good summary, see Kelly, 1998: ch. 7). The main trends in production systems, as portrayed by the more critical and empirical literature, can be summarized briefly. At a conceptual level commentators quickly required a more extended set of analytical categories to make sense of changes in 
patterns of production. Post-Fordism and 'flexible specialization' were joined by 'neoFordism', involving modest changes in product ranges, accompanied by minor changes in levels of work discretion. Neo-Fordism was soon being used to reconceptualize 'lean production' or 'Toyotaism', in which employees participated in the elimination of slack and 'waste' in the production process, reduced cycle-times and minimized task uncertainty (Boyer, 1988; Berggren, 1993; Appelbaum and Batt, 1994; Kelly, 1998: 110-14). Japanese car manufacturers were portrayed as exemplars of product strategies involving 'flexible volume production', a significantly different production model to flexible specialization, with different implications for the labour process and industrial relations (see Berggren, 1993: ch. 1). The concept 'Flex-Fordism' was also used to describe production models based on small-batches and product customization, supported by highly skilled groups of workers, whose skills were mainly of an unreconstructed craft character (Boyer, 1988, Lane, 1995: ch. 8).

A radical disjuncture in production systems and product strategies, adequately described in terms of Post-Fordism, could not be substantiated empirically anywhere.

Attempts to portray developments in public services delivery in post-Fordist terms were also criticized for grossly simplifying complex and contradictory tendencies (Clarke and Newman, 1997: 22-5). The issue of what links there might be between newer forms of production and employment practices increasingly came to be viewed as one which permitted choices mediated by institutional arrangements in different countries and even different regions within countries. How radically industrial relations might change in the context of newer forms of production depended on such choices, and little was preordained by either technology or competitive strategy (Appelbaum and Batt, 1994; Berggren, 1992; Regini, 1995). Notwithstanding such severe qualifications to the early Post-Fordist thesis, data on trends in skill levels in the work-force, where available, confirmed one of the core predictions of the Post-Fordism thesis. The skill content of jobs in both manufacturing and services has indeed risen significantly over the past two decades, and workers across a wide industrial front now exercised more discretion at work (for data on the UK, see Gallie et al., 1998; for the US see Cappelli et al., 1997: ch. 5, and for Germany, see Lane, 1995: 155-6). The issue of what specific link there might be between higher levels of skill and discretion and wider 'new' industrial relations arrangements again quickly became empirically problematic, as will be seen below. 
Empirical reviews of the innovations in service provision associated with the new public management also concluded that the depth and extent of change varied across countries, as well as across services within countries, and was heavily mediated by pre-existing institutional traditions and arrangements (Ferner, 1994; OECD, 1995; 1996; Farnham et al., 1996; Lane and Wolf, 1996). The general trend was towards a more extensive reliance on quasi-market mechanisms to shape service delivery, but within this trend, the UK and New Zealand clearly emerged as 'outliers'. A key role had been assigned in the literature on consumerism to 'newly empowered' public servants, flexible multidisciplinary teams of professionals and to other similar innovations involving qualitative changes in the public service labour process. The reform process, however, emphasized centrally-driven considerations of cost containment and efficiency, which all but swamped consumerist and other 'qualitative' priorities. The greater the degree to which cost and efficiency were emphasized - as borne out in particular by the UK and New Zealand case - the more qualitative service priorities were crowded out (OECD, 1995; 1996; Boston et al., 1996). Cost considerations, however, dominated what the OECD described as the 'integration of people into public service reform' just as they had dominated the reform process more generally (OECD, 1996). The picture of public service provision emerging at the close of the 1990s differs significantly from the dual attainment of enhanced efficiency and greater consumer responsiveness that provided the guiding premise of 'post-bureaucracy' theories of new public services such as that outlined in Reinventing Government. The picture of public service workers that emerged in cases where reform had been driven furthest suggested that the most significant qualitative changes in the public service labour process involved the demoralization of public servants (see Boston et al., 1996 for a discussion of New Zealand and Lane and Wolf, 1990 for a discussion of the US. These themes are almost ubiquitous in the UK empirical literature).

\section{Piecemeal Change in Practices and Compound Employer Strategies}

Research during the 1990s has contributed to a more balanced and sober understanding of the changes wrought in the sphere of employment by new competitive forces. The level and pace of diffusion of industrial relations and human resource practices associated with the new industrial relations have emerged as considerably lower than predicted in the 'first wave' of writing considered above. Research now more commonly emphasizes that much of the change which has occured is piecemeal, ad hoc, 
fragile and marked as much by continuities with older industrial relations and human resource regimes than by disjunctures (Kochan and Osterman, 1994; Pfeffer, 1994; Regini, 1995; Appelbaum and Batt, 1994; Scott, 1994; Millward, 1994; Ichniowski et al., 1996; Roche and Kochan, 1996; Sisson, 1997; Roche, 1999).

The often piecemeal and ad hoc character of change in industrial relations and human resource practices is particularly significant because research has consistently shown that what matters for behaviour and performance in firms is the implementation of consistent 'bundles' of industrial relations and human resource practices (Arthur, 1992; Appelbaum and Batt, 1994; MacDuffie, 1995; Ichniowski et al., 1996; Sisson, 1997). Judging from the international evidence, in particular the evidence for Anglo-Saxon countries, but also available evidence for Continental European countries, innovation involving consistent bundles of new practices has been very uncommon. Thus Regini in an analysis of changing industrial relations in European companies argued that the change process was dominated by what he termed 'pragmatic eclecticism' rather than comprehensive programmes aimed at reconstructing industrial relations in the face of new competitive pressures (Regini, 1995: ch. 7). The valedictory volume of the Industrial Democracy in Europe (IDE) Research Group, felt the need to emphasize the absence still in the 1990s of a 'holistic' or 'systemic' approach to participation, involving a combination of direct and participative approaches, supported by complimentary human resource policies (Heller et al., 1998: ch. 8). Overall, levels of participation appeared little different to what they had been when the IDE group had begun its empirical research in the late 1970s. Still in the 1990s the group judged the prospects for 'democratic practices' in organizations to be 'somewhat limited (Heller et al., 1998: 186). Even in Scandinavian countries, which had been associated with some of the most radical concepts in participation - following the so-called 'socio-technical' model - the evidence was of slow and uncertain diffusion of organizational democracy, with commentators equally despondent as to the outlook for new approaches to work organization and related forms of participation (Heller et al., 1998: 180-6).

Only in the German case are commentators generally in agreement were new production concepts, involving team work and direct involvement, often successfully implanted into an employment model which already possessed a German form of many of the features central to Anglo-Saxon models of new industrial relations: high levels of skills, a strong 
commitment to vocational training, representative participation through works councils and co-determination, internal career paths and a high degree of employment security (Lane, 1995: 134-9). But even in the German case, Post-Fordist forms of work organization have affected only a 'large minority' of manufacturing workers (Lane, 1995: 155, emphasis added). Moreover, German research began to emphasize that even works councils operated differently across sectors, and might even be suppressed or contained by employers, depending on a range of contingent factors (Thelen, 1991; Royle, 1998). Though some UK researchers have tried to argue on the basis of statistical modelling exercises that firms' choices of sets of new practices were more coherent than hitherto believed, the empirical data on which this arguments was based suggested that the incidence of models resembling 'high commitment management' or 'high performance work systems' remained extremely modest (Wood and Albanese, 1995; Wood and de Menzes, 1998). Where coherent or systematic models have been adopted in manufacturing industries, the 'lean production' or 'Toyota model', which accords limited discretion to employees and limited influence to unions, have predominated over so-called 'socio-technical' models, where employees enjoy higher levels of discretion in organizing and managing their work and unions exert greater influence (Berggren, 1993; Appelbaum and Batt, 1994; Grattan, 1997; Sisson, 1997).

In part the limited diffusion of new industrial relations and human resource practices reflect the continuing diversity in developed economies in the competitive postures of firms. Cost-based and value-added competitive strategies coexist in complex patterns. Firms sometimes move serially between alternative strategies in response to specific sets of challenges or constraints. Sometimes they pursue both strategies simultaneously in different business divisions, or different plants. Sometimes competitive postures may seek to incorporate elements of both strategies, or to seek a via media between the rigours of each one (Walton et al., 1994; Locke et al, 1995: ch. 12). To the degree that new industrial relations arrangements are more suited to 'value-added' strategies and adversarialism to 'cost-based strategies', such complex strategic postures by firms may confound simple typologies of industrial relations practices. A further complication introduced by empirical research is the preference of significant numbers of firms to engage in compound or 'mixed' industrial relations and human resource strategies. These can involve a limited and pragmatic willingness to countenance partnership or mutual gains arrangements, allied to a preference, wherever possible, to 'suppress' or 
limit union influence, or to practise 'union substitution' (Kochan et al., 1986; Cooke, 1990; Guest, 1995; Roche and Turner, 1998).

In the United Kingdom 'new industrial relations' became associated during the 1980s with a general willingness by unions to adopt more 'co-operative postures' towards management and sometimes more specifically with a bundle of industrial relations and human resource practices which included single-union recognition agreements, full operational flexibility, no-strike clauses, 'pendulum' or other forms of binding arbitration, flat organizational hierarchies, incorporating simple grading systems and representative company councils. Practices such as these found their locus classicus in the UK plants of Japanese multinationals (Basset, 1986; Oliver and Wilkinson, 1989; Millward, 1994; Kelly, 1996). Their overall incidence, however, was insignificant (Millward, 1994). Empirical studies of exemplars of such arrangements sought to show that they amounted to exercises in shallow pseudo-participation, marked by union weakness and marginalization (Garrahan and Stewart, 1992). Other case-based studies of a wider spectrum of new industrial relations practices and models showed that even well-intentioned 'inclusionary' initiatives were marked by considerable managerial ambivalence, incorporated elements of 'old' and new industrial relations, fell short of expectations and had little real impact on attitudes and behaviour (Scott, 1994). A survey of firms affiliated to the Involvement and Participation Association, and thus likely to be untypically committed to workplace partnership, revealed that less than half saw a necessary role for unions in 'successful partnership organizations'. Many of the practices associated with partnership and new industrial relations in normative models were present to variable and often modest degrees, in particular flexible job design practices, employment security guarantees and financial participation (Guest and Peccei, 1997). Small wonder that UK survey research could point to little evidence of any major change in employee attitudes to employers: they continued, in the main, to be characterized by low trust (Kelly and Kelly, 1991). Nor is it surprising that UK research reveals low levels of 'organizational commitment' on the part of employees (Gallie et al., 1998: ch. 9).

\section{Direct Involvement and Representative Participation}

New industrial relations models assigned importance to the achievement of so-called 'functional flexibility', that is, flexible work practices, cross-training, mobility between 
jobs and related arrangements. A range of studies confirm that work flexibility has been one of the most pervasive trends of the 1980s and 1990s (Locke et al., 1995; Brewster et al., 1994: ch. 11; Kochan and Osterman, 1994: ch. 4; Lane, 1995; Sisson, 1997). What marked out the new industrial relations paradigm, however, was the view that decentralized production strategies might be expected to lead to a fusion of direct employee involvement and representative channels for participation. Developments in 'voice' arrangements have been dominated everywhere by the growing incidence of forms of direct employee involvement based on widening task discretion, team work, task and project groups, quality circles, total quality management programmes, new approaches to communication, and similar voice arrangements (Appelbaum and Batt, 1994; Kochan and Osterman, 1994; Hyman and Mason, 1995; Knudsen, 1995). Commentators differ as to the consequences of this development for collective forms of participation and, in particular, for trade union representation. Some commentators stress that the growth of direct employee involvement has been at the expense of collective channels for employee and union participation. In the case of the UK and the US, Hyman and Mason (1995: ch. 10) argue that the usage of collective involvementoriented joint consultation declined during the 1990s and that "participative collective bargaining' in both countries was becoming increasingly circumscribed by direct involvement techniques. This was the case in spite of the informal ad hoc nature of much employee involvement activity and, relatedly, the often indifferent effects of employee involvement initiatives on behaviour and performance (Hyman and Mason, 1995: 18789).

Hyman and Mason clearly intend their generalization regarding to the growth of direct involvement at the expense of collective forms of participation to apply to Continental Europe, as well as the UK and the US. Knudsen, however, advances a more cautious argument noting that whereas the development of representative participation was almost at a complete standstill since the 1980s, while direct involvement had grown significantly, there existed no strong evidence in European countries generally that direct forms of participation were aimed at replacing or weakening indirect participation and union influence (Knudsen, 1995: ch. 9). Recent reviews of developments in France, however, also suggest that employers have indeed been disposed to bypass and marginalize weak and divided trade unions through the use of forms of direct employee involvement (see Tchobanian, 1995; Streeck, 1995; Lane, 1995: ch. 7). 
For Knudsen, the German and Danish cases pointed to the way in which direct and representative participation could coexist and provide mutual reinforcement (Knudsen, 1995: 160). Streeck and Rogers' major study of works council systems during the 1980s and 1990s reaches a broadly similar conclusion. The general pattern in Continental Europe, they argued, pointed to signs of a " possible renaissance of councils as a workplace-based infrastructure of productive co-operation alongside institutionalized conflict' (Streeck and Rogers, 1995: 19; see also Streeck, 1995). Direct forms of employee involvement had indeed grown in importance in more or less all countries, and many works councils had first resisted this development, as well as the advent of human resource management more generally, as a threat to their regulatory authority. With exception of France, where unions were weak and divided and employers particularly hostile, and of Spain, where unions were under acute pressure to defend their members against widespread rationalization, the trend was towards coexistence between direct and representative participation - the former increasingly integrated with the latter. The evidence prompted Streeck and Rogers to point - albeit very tentatively - towards the possibility of a ' broad if silent movement in the industrial relations of advanced capitalist countries towards a new productivist covenant between capital and labour' (Rogers and Streeck, 1995: 20).

Most analysts agree, however, that the UK and US cases, where no general provisions for representative participation are enshrined by legislation or collective agreements, show a major growth in forms of direct involvement which either bypass unions, seek to undermine, collective bargaining, or provide a means of promoting 'union substitution' In both countries, the incidence of mutual gains or partnership arrangements, which seek to integrate involvement and representative participation, remains modest (see Cooke, 1990; Rogers, 1995; Hyman and Mason, 1995; Gallie et al., 1998: ch. 4). Though it has become common of late to view Ireland as an examplar of Post-Fordist transformation (Sabel, 1996; McCartney and Teague, 1998), the picture there is broadly comparable with other Anglo-Saxon countries. Direct employee involvement is widespread in unionized workplaces, but the incidence of partnership-based approaches, in which unions participate in the handling of change issues, is modest. A recent workplace survey revealed that no more than one in twenty companies favoured partnership to handle any aspect of workplace change during the 1990s. For most areas of change involving 
operational concerns the incidence of partnership is lower. Partnership rarely extends to strategic aspects of plant or company decision-making (Roche and Geary, 1998). The most widely prevalent pattern in Ireland appears to be the growing use of various forms of direct employee involvement accompanied by little concern for how these might be linked with collective representation (see Roche and Kochan, 1996; Roche, 1998)..

The continuing decline in trade union density and influence across most of the advanced economies of Western Europe, North American, Australia and New Zealand, appears to have had ambiguous effects on the uptake of partnership arrangements. On the one hand, declining membership and density have acted as a catalyst for union engagement with new industrial relations practices in countries like the US, the UK and Ireland (Kochan and Osterman, 1994; Ackers and Payne, 1998; Roche and Turner, 1998). On the other hand, in the case of the US, writers have pointed to a vicious circle of weakening trade union power, more aggressive employer attempts to resist or marginalize unions and more highly adversarial industrial relations (see Rogers, 1995; Roche and Kochan, 1996: 55-7). If union power is in decline employers may also be faced with strategic dilemmas at the micro-level and the macro. At the micro-level, the key issue may become why partnership arrangements should be concluded with unions, if the option presents itself of bypassing union channels and emphasizing direct employee involvement. It is clear certainly from the UK evidence and also from data on Ireland that 'dualistic' strategies, focusing on innovations in areas under direct management control, while side-stepping trade unions and collective bargaining, are common (Storey, 1992; Roche and Kochan, 1996; Hyman and Mason, 1995; Roche and Geary, 1998). At the macro-level, employer federations may also be faced with the dilemma as to whether they should support initiatives by the state, or enshrined in law or collective agreements, that might foster the reconstruction of industrial relations, or alternatively whether they should allow current trends to continue unabated in anticipation of further union decline. In the United States, the deadlock surrounding the proposals of the 'Dunlop Commission' on industrial relations illustrates that employers - and governments concerned to accommodate employer opinion - may prefer to underwrite the status quo than to take risks by supporting new institutional arrangements for union-management co-operation (Rogers, 1995). In the case of Ireland, the posture of the main employers' confederation reveals a similar disposition to avoid giving hostages to fortune by emphatically backing union-management partnership at the workplace in compliance 
with the provisions on partnership and involvement contained in the current tripartite national agreement (see Gunnigle, 1998; Roche, 1998; Roche and Geary, 1998).

In Australia and New Zealand such dilemmas have scarcely arisen. The radical neoliberalism of New Zealand governments since the 1980s questioned the very existence of unions, rendering redundant, certainly for public policy, but apparently also for employers generally, the issue of accommodating unions in new industrial relations arrangements (Bray and Walsh, 1998; Boston et al., 1996). In Australia during the greater part of the 1980s the climate facing unions was more benign under the neocorporatist pact between the government and the labour movement. The support provided under central wage accords for co-operative industrial relations at establishment level was seen by Australian and other commentators as a particularly notable development (Lansbury and Niland, 1995; Locke and Kochan, 1995). From the late 1980s, however, when co-operative arrangements at workplace level 'remained sporadic' (Lansbury and Niland, 1995: 87), Australia lunged towards neo-liberalism, and the state introduced provisions for ending unions' representative monopoly. While unions have managed to hold their ground to a greater degree than in New Zealand, neither public policy nor employer priorities any longer focus on seeking new ways of accommodating trade unions (Bray and Walsh, 1998).

\section{Pay Regimes and Employment Security}

Pay regimes internationally have generally been subject to decentralization in response to more intense international competition and employers' search for flexibility (Katz, 1993). This tendency has been far from linear, however, and centralized national or sectorallevel bargaining arrangements remain important in a number of countries (Hyman, 1994; Ferner and Hyman, 1998). Less ambiguous has been a general shift towards what has been described as the 'decollectivization of pay': a shift in the weight of pay determination towards the establishment, growing pay variability within establishments and the increased incidence of individual-level pay determination (Filella and Hegewisch, 1994). Research suggests, however, that much innovation in reward systems has more commonly been piecemeal in character rather than integral to more systematic multistranded change programmes (see Appelbaum and Batt, 1994: ch.5; Kessler, 1995; Hyman and Mason, 1995: ch. 6). 
It is in the area of so-called 'numerical flexibility', the extent to which firms relate their demand for labour to short-term production needs, or alternatively commit themselves to policies emphasizing employment security, that new industrial relations strikes a very distinctive pose and appears most discordant with the weight of empirical evidence on the practices of firms. The first wave of commentary on new industrial relations and associated normative models ws heavily influenced by the 'employment stabilization' policies practised in the case of 'core workers' by a number of companies regarded as exemplars of new industrial relations (Dyer et al., 1985; Kochan et al., 1986). Leaving aside the continuing growth of part-time, temporary and contract employment, regarding which new industrial relations had little to say, research during the 1990s suggests that firms appear more commonly to be softening or abandoning employment stabilization policies for established full-time workers, and relying to a greater extent on external rather than internal labour markets to fill positions across a wide spectrum of occupational categories and layers of management (Cappelli, 1995; Osterman, 1996; Locke et al., 1995; Cappelli et al., 1997). Survey data on new industrial relations and human resource practices suggest that employment stablilization or assurance policies are not commonly associated with other features of new industrial relations models or high commitment management (Osterman, 1994; Wood and Albanese, 1995; McCartney and Teague, 1998; Wood and de Menzes, 1998).

\section{Recruitment and Selection Practices}

While commentators on new industrial relations argued that more flexible, skill-intensive and 'empowered' work systems would lead firms to adopt more sophisticated recruitment and selection practices, the overriding picture emerging from European research on recruitment and selection is the continuing dominance of long-established and 'low validity' - practices, particularly in the case of manual workers where change was expected to be most pronounced (Dany and Torchy, 1994). The behavioural attributes of recruits while relevant to prospective employers (see Cappelli et al., 1997: ch. 5) are seldom of major significance in recruitment decisions, even, it appears, in employment settings where jobs are becoming more complex (for data on the US, see Osterman, 1995, and for UK data, see Penn et al., 1993). The importance of this finding is magnified by data for the UK which show that 'social skills', particularly skills required to 'work with people', are now particularly significant across a range of industries and services (Gallie et al., 1998: 50-5). UK survey data suggest that 
organizations in the public and private sectors commonly view 'social skills' and 'team working skills' as important selection criteria (see Wood and Albanese, 1995; Wood and de Menzes, 1988). However, survey questions which seek evidence of the incidence of specific selection practices designed to 'filter' recruits systematically on the basis of such skills present a different picture. The preliminary results of the 1998 UK Workplace Employee Relations Survey, for example, report that only 20 per cent of establishments utilize attitudinal tests before making appointments (Cully et al., 1998: 10). Survey data for Ireland reveal a similar picture (Heraty and Morley, 1998). Windolf and Wood's case studies of recruitment and selection practices in large German and UK companies show that managers are indeed concerned to reproduce the 'social relations' of the company and to that end take account of the attitudes of prospective recruits. They do so, however, through largely informal 'filtering' processes (Windolf and Wood, 1988). Such an 'intuitive' approach is far removed from the formal, detailed and rigorous selection and socialization practices associated with the new industrial relations (see Wickens, 1987; Townley, 1989; Pascale, 1985; Berggren, 1992: 37-9; Kochan and Osterman, 1994; Pfeffer, 1994: 33-4; Graham, 1995). Also relvant, is recent research on team working in European countries which shows that discretion to select team members - one indicator of advanced forms of team work - is seldom accorded to existing members of teams (Sisson, 1997). The same holds for the United States (Berggren, 1992; Appelbaum and Batt, 1994).

\section{Marketized Public Sectors and Human Resource Priorities}

The picture emerging from recent research on the public sectors of advanced economies is consistent with empirical work on developments in the private sector. It has proven difficult in practice to develop and implement coherent strategies for human resource management and industrial relations (OECD, 1996). This sometimes reflects political ambiguity and vacillation over reform proposals and legal complications over the status of new organizational forms (for illustrations from the UK, see Corby, 1993/94, and Bach and Winchester, 1994). In commercial public enterprises, the complexity of the process of strategy formulation has also been emphasized, including the permeability of political decision-making above the level of the enterprise to lobbying and obstruction tactics by unions and management (Ferner, 1988). Organizational strategies which are politically mediated and open to political challenge appear highly susceptible to abrupt changes of tempo, or even of direction, to inconsistent interventions by governments 
and to the dilution of politically risky change programmes. A strategic context such as this poses major and perhaps quite distinctive problems for industrial relations and human resource strategies and their champions in the public domain (Ferner, 1988; Hastings, 1994; Bach, 1994/95; Bach and Winchester, 1994).

In the UK and New Zealand, where radical reforms to institute quasi-market measures and introduce public executive public service agencies have proceeded furthest, much of the work of human resource managers has been bogged down in handling rationalization, cost-cutting and head-count reduction (Bach, 1994/5; Boston et al., 1996). The more constructive objectives associated with new models have been displaced or muted by the effects of radical organizational change, especially the effects on employee morale. In the UK research as shown that human resource managers in health service trusts are viewed by line managers as least effective in the newer and more strategic areas of their remit (Bach, 1994/95). As in the private sector, the general trend in public service pay determination has been towards decentralization. Greater "pay flexibility' has been instituted through such measures as department and agency-level pay fixing, devolved administrative budgets, greater scope for regional pay variation, and the use of pay supplements to recruit and retain scarce staff categories (OECD, 1993a). Performance-related pay, in particular, has been widely adopted in public enterprises and agencies, but the weight of evidence indicates that it has largely proven ineffective in improving motivation and performance, and that it is not viewed by public sector workers as of major significance as a source of employment satisfaction (OECD, 1993b; 1997; Marsden and Richardson, 1994; Marsden and French, 1998). Attempts to promote total quality management and related approaches to service delivery and to achieve greater flexibility in work organization court resistance by powerful occupational and professional groups and their unions, intent on rigorously policing the boundaries of their jobs, and often dismissive of the consumerist principles animating change programmes (see Epstein, 1990; Clarke and Newman, 1997: ch.6). Often, it appears, cost constraints have in any case forced public service agencies to 're-profile' work by transferring tasks previously performed by skilled groups to unskilled and semi-skilled workers and by increasing numbers of lower-skilled workers (Bach and Winchester, 1994; Bach, 1994/5). 
Reviews of developments in voice arrangements in European public sectors point mainly to the development of more formalized collective bargaining arrangements and associated modes of dispute resolution. Few significant changes have been observed in the operation of public service works councils in countries where they exist (Treu, 1987; Ferner, 1993). Newly created civil service agencies in the UK appear either to have maintained the status quo with respect to employee voice, or to have attempted to bypass unions through 'dualist' approaches emphasizing direct employee involvement (Corby, 1993/94; 1998). Partnership arrangements hardly figure at all in reviews of the new public service agencies. Essentially the same picture holds for national health service trusts (Bach and Winchester, 1994; Bach, 1994/95; Corby, 1996). Reviews of developments in local government point to a small number of experiments in new bargaining arrangements, such as 'single-table' bargaining and the adoption of 'pendulum arbitration' for clerical and administrative grades by a handful of local authorities. But overall the picture is one of little change in voice arrangements (Jackson, et al., 1993).

In the United States, the concern of the first Clinton administration to control the scale and cost of the federal government led in 1993 to proposals by Vice-President Gore to 'reinvent' government. 'Partnership' is one of a series of innovations proposed to promote higher quality, more responsive and more cost effective federal services. A 1993 executive order by President Clinton aimed to clear the way towards partnershipbased collective bargaining in federal agencies. The prospects of new arrangements replacing entrenched adversarial bargaining structures have yet to be determined (see Suntrup and Barnum, 1997). A survey of partnership-based arrangements in state and local government indicated that a higher incidence of such arrangements existed in the mid 1990s than in the private sector. Public sector workers, however, were only half as likely as private sector workers to view such programmes as effective, and only 20 per cent rated existing participation mechanisms as 'very effective' in improving productivity or quality (US Department of Labor, 1996: ch. 3; and see also Balliet, 1997).

While some changes in recruitment and selection practices are reported in the literature, on the whole the main changes in these areas appear to have involved the administrative devolution to departments and agencies of a higher level of discretion to adopt their own recruitment programmes rather than having to avail of the services of centralized 
civil service commissions or similar bodies. Otherwise little appears to have changed with respect to how public servants are selected or 'socialized', or with respect to the role of behavioural or qualitative concerns in public service performance management systems (see OECD, 1996 for a review of relevant changes and see Marsden and French, 1998 for an analysis of the residual role of qualitative factors in UK public service performance management systems).

\section{The Future of New Industrial Relations}

The results emerging from the 'second wave' of literature on new industrial relations during the 1990s can be summarized in brief before considering alternative arguments as to the future of industrial relations systems in advanced economies.

1. Extensive experimentation with new industrial relations and human resource practices has been evident in many countries and in both private and public sectors. Much of the change, however, has been piecemeal, fragile and ad hoc, less focused on instituting a coherent alternative to the adversarial model than on responding to specific challenges in a largely pragmatic way. German manufacturing industry may be exceptional in the degree to which new production concepts have fused with the pre-existing dual model and its associated bundle of employment practices. Generally, where coherent models have been developed, they have mainly been of a type which both curtails the discretion available to employees to organize their work and restricts the decision-making role of trade unions. Where work has been upskilled and task discretion expanded, employees may still enjoy only very limited participation in wider aspects of employment and organizational decision-making (Berggren, 1992; Appelbaum and Batt, 1994; Gallie et al., 1998). So even the link posited by PostFordism between higher levels of skill or task discretion and new forms of participation has been called into question by the empirical evidence. Policies of employment security for core workers, viewed from the outset of the debate certainly in Anglo-Saxon countries - as a pillar of new industrial relations arrangements, seem commonly to be unforthcoming or inoperable. In public sector organizations coherent sets of innovations have proven at least as difficult to institute as in the private sector. The widespread adoption of performance-related pay has not led to the results expected. The market-oriented reforms associated with managerialism and consumerism and their human resource and industrial relations effects have often led to the prioritization of cost-cutting and rationalization at the 
expense of more constructive HRM and industrial relations objectives. New forms of public service delivery, in which marketization and qualitative changes focused on the consumer are mutually reinforcing, have yet to emerge on any widespread basis. Public service employment appears in most countries to have become less secure for progressively larger numbers of public service workers.

2. The competitive postures of employers, their production systems and industrial relations strategies continue to be highly variable and often harbour compound and even incompatible objectives. The flexible product and production strategies widely seen to provide a platform for the development of new forms of industrial relations are variably present in all economies, but nowhere represent a dominant new economic model. (Cutler et al., 1987; Locke and Kochan, 1995; Lane, 1995).

3. In the light of these and other findings, the emphasis in the first wave of literature on 'transformation' is misplaced and misleading. The cumulative weight of innovations do not add up to a generalized alternative to the adversarial model or other 'Fordist' models. New industrial relations have not displaced 'old' in a generalized transformative process driven by economic pressures and new systems of production and service delivery.

But what of the future of new industrial relations practices and arrangement? Do the empirical developments reviewed point to the beginnings of new industrial relations or do they suggest the end of the paradigm as a generalized model for advanced economies? Could developments over the past decade plausibly still be viewed as reflecting a period of transition to a new industrial relations regime - a longer and more difficult transition than anticipated, perhaps, but one in which the end in sight is still broadly in conformance with the 'first-wave' literature? Alternatively, might generalized experimentation with new industrial relations and human resource practices have peaked and might the future involve increasingly diverse industrial relations models and arrangements? To consider these questions it is necessary to turn to recent reflection and debate on comparative industrial relations trends. A number of distinct, if overlapping, arguments can be identified and will be considered in turn.

\section{New Industrial Relations Through Grand Programmes of Institutional}

\section{Redesign?}


In the light of empirical trends in the US, commentators have argued that nothing short of a major programme of institutional change, incorporating reforms to industrial relations structures, education and training, corporate governance arrangements and other key areas, will be required if quality-focused competitive strategies, supported by a new industrial relations regime, are to become embedded in the US economy (Kochan and Osterman, 1994: chs. 7-9; Appelbaum and Batt, 1994: chs. 9-10; Pfeffer, 1994: chs. 9-10; 1998: ch. 9; Rogers, 1995). Understandably, little optimism exists among these commentators that such a programme is at all likely to be implemented. The pessimism of contributors to a symposium on the 'Dunlop Report', published in Industrial Relations (34(3), 1995), was revealing as to the low morale of liberal commentators concerning the prospects for change in industrial relations institutions (see, in particular, Kochan, 1995).

The emphasis of US commentators on the redesign of institutions as a prerequisite for new industrial relations finds resonance with the EU 'social project' of creating a European industrial relations system by harmonizing representative and other arrangements across Community countries, particularly along the lines of the German model of industrial relations. The EU programme continues to have some momentum, most recently leading to the establishment of 'European works councils' in companies with plants in two or more members states. Commission proposals on new forms of work organization are also heavily permeated by the language of 'partnership' (European Commission, 1997). From its inception, however, the progress of the EU social project in the industrial relations sphere has been very modest, and commentators have argued that the grand strategy of creating a 'European industrial relations system' is all but dead (see Streeck, 1992; 1994). Scenarios that point to major programmes of institutional change as a prerequisite or coexistence-requisite for the institutionalization of new industrial relations thus seem unlikely to come to pass on either side of the Atlantic.

\section{Inter-regime Competition and the Generalized Demise of New Industrial Relations} ?

A second perspective associated in particular with the work of Streeck has been influenced by both the failure of competitive trends in advanced economies to institute a new industrial relations regime and the implausibility of supposing that such a regime 
will emerge through grand programmes of institutional change. Streeck has argued that European industrial relations systems can be expected to diverge, as significant differences between countries and regions in labour cost, productivity, levels of education and skill, and degrees of labour market protection, prompt governments to realign national and possibly regional industrial relations regimes to fit with broader competitive postures and opportunities. Programmes of realignment, which would involve attempts to engender higher levels of consistency between various labour market and industrial relations policies, might, in turn, be expected to engender 'regime competition' and 'bidding wars' between public authorities, as they struggled to attract and retain foreign direct investment (Streeck, 1992). The outcome will be increased variation in industrial relations arrangements between European nations and possibly between sub-national regions. Such an outcome represents only a first phase in Streeck's favoured scenario. The possibilities available to employers to engage in 'regime shopping' and to defect, or threaten to defect, from industrial relations regimes characterized by strong representative institutions and extensive labour market protection, could be expected to result in a progressive erosion of more exacting employment standards and regulatory arrangements. Streeck's bleak long-run scenario is the progressive demise within Europe of industrial relations regimes closest to the vision associated with new industrial relations.

Streeck is emphatic that the co-operative industrial relations arrangements which exist in many works councils systems, could only have arisen and can only survive by being buttressed by legislation or national agreements between employers and unions (Streeck, 1992; Streeck, 1995; Rogers and Streeck, 1995). Voluntary forms of management-union co-operation, he argues, are rendered chronically unstable by the possibility that management might choose to defect in response to short-term pressures. As such, the dilution of existing institutional supports to co-operation between employers and unions, which is likely to be engendered by 'regime competition', can only have damaging consequences for 'collaborative production' (Streeck, 1992).

\section{Regime Fragmentation and the Contingent Adoption of New Industrial Relations?}

A third perspective resembles Streeck's scenario, but shorn of its bleak long-run prediction concerning the generalized demise of regimes premised on new industrial relations principles. In this perspective new industrial relations models of different types 
are expected to remain significant in advanced economies, but in highly contingent circumstances and nowhere as a generalized model of employment relations.

Locke (1992) and Darbyshire and Katz (1997) have argued that distinctive national industrial relations systems may be disappearing in the face of a trend towards wider variation within countries with respect to models of employment than between models characteristic of each country. This scenario, aptly described by Darbyshire and Katz as 'converging divergence', points to a steady state in which sharply diverging models will coexist at firm and establishment level within nations. The Darbyshire-Katz scenario was initially informed by a study of industrial relations trends internationally in telecommunications (Katz, 1997). Reviewing developments in industrial relations more generally in Australia, Germany, Italy, Sweden, the United Kingdom, the United States and Japan, Darbyshire and Katz find increasing variation in employment practices across a number of industries in all cases. They also identify four generic workplace industrial relations models which represent commonalities in the nature of the variation that is now appearing in all these countries. A 'low-wage pattern' is based on managerial discretion, a strongly anti-union animus, hierarchical work relations, procedural informality, low wages and high turnover. A 'HRM pattern' involves an emphasis on the creation and maintenance of a corporate culture, supported by extensive communication practices, the use of teams subject to management direction, high pay with heavily individualized rewards and career paths and union substitution. A 'Japanese-oriented pattern' involves problem solving teams, standardized procedures, high pay linked to seniority and performance appraisals, employment stablization practices, and enterprise unions. Finally, a 'joint team-based pattern' involves joint decision-making, incorporating unions and embracing semi-autonomous work groups, high pay and contingent reward systems and an emphasis on career development (Darbyshire and Katz, 1997). Whether these generic models are an adequate representation of the range of variation is not a concern of this paper. It may be a misatake, however, to suppose that strongly marketized models of industrial relations are restricted to 'low wage' employments (see especially Cappelli, 1995). It is clear, nevertheless, that the joint teambased pattern and, perhaps, the Japanese-oriented pattern come closest to new industrial relations arrangements as understood in the wider literature. 
The adoption of these patterns by firms and establishments reflects differing assessments of the most effective way to respond to competitive imperatives and pre-existing constraints and opportunities at local level. The relative incidence of the patterns, in particular the relative incidence of arrangements based on new industrial relations principles and their detailed articulation in practice, vary significantly across the countries studied. The pattern of variation - lowest in Germany, highest in the UK and the US - reflect in major degree what Hyman has called the 'institutional inertia' engendered by pre-existing national systems of collective bargaining, interest representation and politics (cf. Hyman, 1994: 20).

Darbyshire and Katz are emphatic that firms in the countries studied firms are not observed to be 'striving for a single 'best practice' model of work organization' (Darbyshire and Katz, 1997: 4). Nor do they propose that any secular trend exists such as might favour any model(s) of employment over others in the long-term. The future is one in which diverse employment models will continue to coexist. This position also implies the end of new industrial relations as a generalized paradigm for advanced economies, but the continuing currency of new industrial relations in contingent competitive and organizational conditions. More significant for the subject of this paper than the differences between the Streeck scenario and the scenario of regime fragmentation is their common prediction that new industrial relations principles are highly unlikely to become the basis for a generalized employment regime in advanced economies.

\section{Conclusion}

An influential body of literature during the 1980s predicted the growing diffusion or generalization of new industrial relations arrangements as a consequence of Post-Fordist production strategies and post-bureaucratic forms of public management. This paper has examined a significant and diverse empirical and review literature which accumulated mostly during the 19990s and covered more detailed aspects of change in industrial relations and human resource practices in firms and public sector organizations. The weight of the empirical evidence now to hand calls into serious question the extent to which new industrial relations arrangements have come into being in advanced economies. Moreover, the most convincing scenarios as to the likely trajectory of industrial relations in advanced economies suggest that the slow and uneven 
development of new practices in most countries cannot be attributed to a prolonged phase of 'transition'. While differing in important respects, the Streeck and DarbyshireKatz scenarios both predict that new industrial relations will not become the basis of a generalized employment paradigm. 


\section{REFERENCES}

Ackers, P. and Payne, J. (1998) 'British Trade Unions and Social Partnership: Rhetoric, Reality and Strategy', International Journal of Human Resource Management, 9: 529-50.

Appelbaum, E. and Batt, R. (1994) The New American Workplace. Ithica, New York: ILR Press.

Arthur, J.B., (1992) 'The Link Between Business Strategy and Industrial Relations Systems in American Steel Minimills', Industrial and Labor Relations Review, 45: 488-506.

Bach, S. (1994/95) 'Restructuring the Personnel Function: The case of NHS Trusts', Human Resource Management Journal, 5: 99-115.

Bach, S. and Winchester, D. (1994) 'Opting Out of Pay Devolution? The Prospects for Local Pay Bargaining in UK Public Services', British Journal of Industrial Relations, 32: 263-82.

Bailet, L. (1997) 'Labor-Management Partnerships in State and Local Government', in B. Nissen (ed) Unions and Workplace Reorganization, pp. 159-180. Detroit: Wayne State University.

Basset, P. (1986) Strike Free: New Industrial relations in Britain. London: Macmillan.

Bendix, R. (1956) Work and Authority in Industry. New York: Wiley.

Berggren, C. (1993) Alternatives to Lean Production: Work Organization in the Swedish Auto Industry. Ithica, New York: ILR Press.

Best, M. (1990) The New Competition: Institutions of Industrial Restructuring. London: Cambridge: Polity Press.

Boston, J. Martin, J. Pallot, J. and Walsh, P. (1996) Public Management: The New Zealand Model. Oxford: Oxford University Press.

Boyer, R. (1988) The Search for Labour Market Flexibility. Oxford: Clarendon Press.

Bray, M. and Walsh, P. (1998) 'Different Paths to Neo-Liberalism? Comparing Australia and New Zealand', Industrial Relations, 37: 358-86.

Brewster, C. and Hegewisch, A. eds (1994) Policy and Practice in European Human Resource Management: The Price Waterhouse Cranfield Survey. London: Routledge.

Cappelli, P. (1995) 'Rethinking Employment', British Journal of Industrial Relations, 31: 1-24.

Cappelli, P., Bassi, L., Katz, H., Knoke, D., Osterman, P. and Useem, M. (1997) Change at Work. New York; Oxford University Press.

Clark, J. and Newman, J. (1997) The Managerial State: Power, Politics and Ideology in the Remaking of Social Welfare. London: Sage.

Cooke, W.N. (1990) Labor-Management Cooperation. Kalamazoo, Michigan: W.E. Upjohn Institute for Employment Research.

Corby, S. (1998) 'Industrial Relations in Civil Service Agencies: Transition or Transformation', Industrial Relations Journal, 29: 194-206.

Corby, S. (1993/94) 'How Big a Step is "Next Steps"? Industrial Relations Development in Civil Service executive Agencies', Human Resource Management Journal, 4: 52-69.

Crouch, C. and Pizzorno. A. eds (1978) The Resurgence of Class Conflict In Western Europe Since 1968. (2 vols) London: Macmillan.

Cully, M., O'Reilly, A., Millward, N. Forth, J., Woodland, S., Dix, G. and 
Bryson, A. (1998) The 1998 Workplace Employee Relations Survey: First

Findings. London: Department of Trade and Industry.

Cutler, T., Haslam, C., Williams, J. and Williams, K. (1987) 'The End of Mass

Production?, Economy and Society, 16: 405-38.

Dany, F. and Torchy, V. (1994) 'Recruitment and Selection in Europe: Policies, Practices and methods', in C. Brewster and A. Hegewisch (eds)

Policy and Practice in European Human Resource Management: The Price Waterhouse Cranfield Survey, pp. 68-88. London: Routledge.

Darbyshire, O. and Katz, H. (1997) 'Converging Divergences: Worldwide Changes in Employment Relations'. School of Industrial and Labor Relations, Cornell University.

Dyer, L., Milkovich, G. and Foltman, F. (1985) 'Contemporary Employment Stabilization Practices', in T. Kochan and P. Barocci (eds) Human Resource Management and Industrial Relations, pp. 207-9. Boston: Little Brown.

Epstein, J. (1990) Public Services: Working for the Consumer. Dublin; European Foundation for the Improvement of Living and Working Conditions.

European Commission (1997) Partnership for a New Organization of Work. Luxembourg: Office for Official Publications of the European Communities.

Farnham, D., Horton, S., Barlow, J. and Hondeghem, A. (1996) New Public Managers in Europe: Public Servants in Transition. London: Macmillan.

Ferner, A. (1994) 'The State as Employer', in R. Hyman and A. Ferner (eds) New Frontiers in European Industrial Relations. Oxford: Blackwell.

Ferner, A. (1988) Governments, Managers and Industrial Relations: Public Enterprises and their Political Environments. Oxford: Blackwell.

Ferner, A. and Hyman, R. (1998) ' Introduction; Towards European Industrial Relations?', in A. Ferner and R. Hyman (eds) Changing Industrial Relations in Europe, pp. xi-xxvi. Oxford: Blackwell.

Filella, J. and Hegewisch, A. (1994) 'European Experiments With Pay and Benefits Policies', in C. Brewster and A. Hegewisch (eds) Policy and Practice in European Human Resource Management: The Price Waterhouse Cranfield Survey, pp. 89-106. London: Routledge.

Gallie, D., White, M., Cheng, Yuan and Tomlinson, M. (1998) Restructuring the Employment Relationship. Oxford: Clarendon Press.

Garrahan, P. and Stewart, P. (1992) The Nissan Enigma: Flexibility at Work in a Local Economy. London: Mansell.

Goldthorpe, J.H. ed (1984) Order and Conflict in Contemporary Capitalism. Oxford: Clarendon Press.

Guest, D.E. (1995) 'Human Resource Management, Trade Unions and Industrial relations', in J. Storey (ed) Human Resource Management: A Critical Text, pp. 110-42. London: Routledge.

Guest, D.E. and Peccei, R. (1997) The Partnership Company: Benchmarks for the Future. London: IPA.

Graham, L. (1995) On the Line at Subaru-Isuzu. Ithica, New York: ILR Press.

Grattan, J. (1997) 'Worker Democracy and Employee Involvement Plans', in B. Nissen (ed) Unions and Workplace Reorganization, pp. 78-92.

Detroit: Wayne State University Press.

Gunnigle, P. (1998) 'More Rhetoric than Reality: Enterprise Level Industrial Relations Partnership in Ireland', Economic and Social Review, 28: 179-200.

Harrow, J. and Shaw, M. (1992) 'The Manager Faces the Consumer', in L. Willcocks and J. Harrow (eds) Rediscovering Public Services Management, pp. 113-40. London: McGraw Hill. 
Hastings, T. (1994) Semi-States in Crisis, Dublin: Oak Tree Press.

Heller, F., Pusic, E., Strauss, G. and Wilpert, B. (1998) Organizational Participation. Oxford: Oxford University Press.

Heraty, N. and Morley, M. (1998) 'Recruitment and Selection Practices', in W.K. Roche, K. Monks and J. Walsh (eds) Human Resource Strategies: Policy and Practice in Ireland, pp.109-46. Dublin: Oak Tree Press.

Hyman, J. and Mason, B. (1995) Managing Employee Involvement and Participation. London: Sage.

Hyman, R. (1994) 'Industrial Relations in Western Europe: An Era of Ambiguity?', Industrial Relations, 33: 1-24.

Ichniowski, C., Kochan, T., Levine, D., Olson, C. and Strauss, G. (1996) 'What Works at Work?' Industrial Relations, 35: 299-333.

Jackson, M.P., Leopold, J.W., Tuck, K. (1993) Decentralization of Collective Bargaining: An Analysis of Recent Experience in the UK. London/New York: Macmillan/St Martin's Press.

Katz, H. ed (1997) Telecommunications: Restructuring Work and Employment Relations Worldwide. Ithica, New York: ILR Press.

Katz, H. (1993) 'Decentralization of Collective Bargaining', Industrial and Labor Relations Review, 47: 3-22.

Kearney, R.C. and Hays, S. (1994) 'Labor-Management Relations and Participative Decision Making: Toward a New Paradigm', Public Administration Review, 54: 44-51.

Kelly, J. (1998) Rethinking Industrial Relations: Mobilization, Collectivism and Long Waves. London: Routledge.

Kelly, J. (1996) 'Union Militancy and Social Partnership' in P. Ackers, C. Smith and P. Smith (eds) The New Workplace and Trade Unionism, pp. 77-109. London: Routledge.

Kelly, J. and Kelly, C. (1991) "Them and Us": Social Psychology and the New Industrial Relations', British Journal of Industrial Relations, 29: 25-48.

Kern, H. and Schumann, M. (1984) Das Ende der Arbeitsteilung? Munich: Verlag C.H. Beck.

Kernahan, K. (1993) 'Partnership and Public Administration: Revolutionary Advance or Passing Fancy?', Canadian Public Administration, 35: 194-214.

Kerr, C., Dunlop, J.T., Harbison, F and Myers, C.A. (1960) Industrialism and Industrial Man. Cambridge Mass.: Harvard University Press.

Kessler, I. (1995) 'Reward Systems', in J. Storey (ed) Human Resource Management: A Critical Text, pp. 254-279. London: Routledge.

Knudsen, H. (1995) Employee Participation in Europe. London: Sage.

Kochan, T., Lansbury, R., MacDuffie, J.P. eds (1997) After Lean Production: Evolving Employment Practices in the World Auto Industry. Ithica, New York: ILR Press.

Kochan, T. (1995) 'Using the Dunlop Report to Achieve Mutual Gains', Industrial Relations, 34: 351-66.

Kochan, T. and Osterman, P. (1994) The Mutual Gains Enterprise: Forging a Winning Partnership Among Labor, Management and Government. Boston Mass.: Harvard Business School Press.

Kochan, T., Katz, H. and McKersie, R. (1986) The Transformation of American Industrial Relations. New York: Basic Books.

Lane, C. (1995) Industry and Society in Europe: Stability and Change in Britain, Germany and France. Aldershot: Edward Elgar. 
Lane, J.E. (1996) Public Sector Reform: Rationale, Trends and Problems. London: Sage.

Lane, L.M. and Wolf., J.E. (1990) The Human Resource Crisis in the Public Sector: Rebuilding the Capacity to Govern. New York: Quorum Books.

Lansbury, R. and Niland, J. (1995) 'Managed Decentralization? Recent Trends in Australian Industrial Relations and Human Resource Policies', in Locke, R., Kochan, T. and Piore, M. eds (1995) Employment Relations in a Changing World Economy, pp. 59-90. Cambridge Mass.: The MIT Press.

Locke, R. (1992) 'The Demise of the National Union in Italy: Lessons for Comparative Industrial Relations Theory', Industrial and Labor Relations Review, 45: 229-49.

Locke, R., Kochan, T. and Piore, M. eds (1995) Employment Relations in a Changing World Economy. Cambridge Mass.: The MIT Press.

McCartney, J. and Teague, P. (1998) 'Workplace Innovations in the Republic of Ireland', Economic and Social Review, 28: 381-99.

McDuffie, J.P. (1995) 'Human Resource Bundles and Manufacturing Performance: Organizational Logic and Flexible Production Systems in the World Auto Industry', Industrial and Labor Relations Review, 48: 197-221.

Marsden, D. and French, S. (1998) What a Performance: Performance-Related Pay in the Public Services. London: Anglo-German Foundation.

Marsden, D. and Richardson, R. (1994) 'Performing for Pay? The Effects of Performance Pay on Motivation in a Public Service', British Journal of Industrial Relations, 32: 343-60.

Millward, N. (1994) The New Industrial Relations? London: Policy Studies Institute.

OECD (1997) Performance Pay for Public Sector Managers: An Evaluation of the Impacts. Occasional Paper No 15, Paris: OECD.

OECD (1996) Integrating People into Public Service Reform. Paris: OECD.

OECD (1995) Governance in Transition: Public Management Reforms in OECD Countries. Paris: OECD.

OECD (1993a) Private Pay for Public Work: Performance-Related Pay for Public Sector Managers. Paris: OECD.

OECD (1993b) Pay Flexibility in the Public Sector. Paris: OECD.

OECD (1990) Flexible Personnel Management in the Public Service. Paris: OECD.

Oliver, N. and Wilkinson, B. (1989) The Japanization of British Industry. Oxford: Blackwell.

Osborne, D. and Gaebler, T. (1993) Reinventing Government. New York: Plume.

Osterman, P. (1995) 'Skills, Training and Work Organization in American Establishments', Industrial Relations, 34: 125-46.

Osterman, P. ed (1996) Broken Ladders: Managerial Careers in the New Economy. New York: Oxford University Press.

Pascale, R. (1985) 'The Paradox of Corporate Culture: Reconciling Ourselves to Socialization', California Management Review, 27: 26-41.

Penn, R. Rose, M. and Rubery, J. (1993) Skill and Occupational Change. Oxford: Oxford University Press.

Pfeffer, J. (1994) Competitive Advantage Through People: Unleashing the Power of the Work Force. Boston Mass.: Harvard Business School Press.

Piore, M. and Sabel, C. (1984) The Second Industrial Divide. New York: Basic Books.

Potter, J. (1998) 'Consumerism in the Public Sector: How Well Does the 
Coat Fit', Public Administration, 66: 149-64.

Regalia, E. and Regini, M. (1995) 'Between Voluntarism and Institutionalization: Industrial Relations and Human Resource Practices in Italy', in R. Locke, T. Kochan and M. Piore (eds) Employment Relations in a Changing World Economy, pp. 131-63. Cambridge Mass.: The MIT Press.

Regini, M. (1995) Uncertain Boundaries: The Social and Political Construction of European Economies. Cambridge: Cambridge University Press.

Roche, W.K. and Kochan, T. (1996) Strategies for Extending Social Partnership to Enterprise and Workplace Levels in Ireland. Dublin: Report Presented to the National Economic and Social Council.

Roche, W.K. (1998) 'Between Regime Fragmentation and Realignment: Irish Industrial relations in the 1990s', Industrial Relations Journal, 29: 112-25.

Roche, W.K. and Turner, T. (1998) 'Human Resource Management and Industrial Relations: Substitution, Dualism and Partnership', in W.K. Roche, K. Monks and J. Walsh (eds) Human Resource Strategies: Policy and Practice in Ireland, pp. 67-108. Dublin: Oak Tree Press.

Roche, W. K. and Geary, J. (1998) 'Collaborative Production and the Irish Boom: Work Organization, Involvement and partnership in Irish Workplaces', Working Paper, Centre for Employment Relations and Organizational Performance, Graduate School of Business, University College Dublin.

Roche, W.K. (1999) 'In Search of Commitment-Oriented Human Resource Practices and the Conditions Which Sustain Them', Journal of Management Studies, 36 (forthcoming).

Rogers, J. (1995) ' United States: Lessons from Abroad and Home', in in J. Rogers and W. Streeck, (eds) Works Councils: Consultation, Representation and Cooperation in Industrial Relations, pp. 375-410. Chicago and London: University of Chicago Press.

Rogers, J. and Streeck, W. (1995) 'The Study of Works Councils: Concepts and Problems', in J. Rogers and W. Streeck, (eds) Works Councils: Consultation, Representation and Cooperation in Industrial Relations, pp. 3-26. Chicago and London: University of Chicago Press.

Royle, T. (1998) 'Avoidance Strategies and the German System of Co-Determination', International Journal of Human Resource Management, 9: 1998: 1026-1047.

Sabel, C. (1996) Ireland: Local Partnerships and Social Innovation. Paris: OECD.

Scott, A. (1994) Willing Slaves: British Workers Under Human Resource Management. Cambridge: Cambridge University Press.

Sisson, K. ed (1997) Towards New Forms of Work Organisation - Can Europe Realise Its Innovative Potential? An Interim Report of the EPOC Questionnaire Survey of Direct Employee Participation in Europe. Luxembourg: European Foundation/Office for the Official Publication of the European Communities.

Storey, J. (1992) Developments in the Management of Human Resources, Oxford: Blackwell.

Storey, J. (1989) 'Human Resource Management in the Public Sector', Public Money and Management, 9:

Streeck, W. (1995) 'Works Councils in Western Europe: From Consultation to Participation', in J. Rogers and W. Streeck, (eds) Works Councils: Consultation Representation and Cooperation in Industrial Relations, 
pp. 313-350. Chicago and London: University of Chicago Press.

Streeck, W. (1994) 'European Social Policy after Maastricht: The "Social

Dialogue" and "Subsidiarity"?', Economic and Industrial Democracy,

15: $151-77$.

Streeck, W. (1992) 'National Diversity, Regime Competition and Institutional Deadlock: Problems in Forming a European Industrial Relations System', Journal of Public Policy, 12: 301-30.

Suntrup, E.L. and Barnum, D.T. (1997) 'Reinventing the Federal Government: Forging New Labor-Management Partnerships for the 1990s', in B. Nissen (ed) Unions and Workplace Reorganization, pp. 145-58. Detroit: Wayne State University.

Tchobanian, R. (1995) 'France: From Conflict to Social Dialogue?', in J. Rogers and W. Streeck, (eds) Works Councils: Consultation, Representation and Cooperation in Industrial Relations, pp. 115-52. Chicago and London: University of Chicago Press.

Thelen, K. (1991) Union of Parts: Labor Politics in Postwar Germany. Ithica, New York: ILR Press.

Townley, B. (1989) 'Selection and Appraisal: reconstituting Social Relations', in J. Storey (ed) New Perspectives on Human Resource Management, pp. 92-108. London: Routledge.

Treu, T. ed (1987) Public Service Labour Relations: A Comparative Study of Seven Industrialised Market Economies. Geneva: International labour Office.

US Department of Labor (1996) Working Together for Public Service. Washington DC: US Department of Labor.

Walsh, K. (1994) 'Citizens, Charters and Contracts', in R. Keat, N. Whiteley, and N. Amercrombie (eds) The Authority of the Consumer. London: Routledge.

Walton, R.E., Cutcher-Gershenfeld, J. and McKersie, R.B. (1994) Strategic Negotiations: a Theory of Change in Labor-Management Relations. Boston Mass.: Harvard Business School Press.

Wickens, P. (1987) The Road to Nissan. London: Macmillan.

Windolf, P. (1989) 'Productivity Coalitions and the Future of European Corporatism', Industrial Relations, 28: 1-20.

Windolf, P. and Wood, S. with Hohn, H.W. and Manwaring, T. (1988) Recruitment and Selection in the Labour Market. Aldershot: Gower.

Womack, J.P., Jones, D.T. and Roos, D. (1990) The Machine That Changed the World. New York: Rawson Associates.

Wood, S. and Albanese, M.T. (1995) 'Can We Speak of High Commitment Management On the Shop Floor?', Journal of Management Studies, 32: 215-47.

Wood, S. and de Menzes, L. (1998) 'High Commitment Management in the UK: Evidence from the Workplace Industrial relations Survey and Employers'

Manpower and Skills Practices Survey', Human 